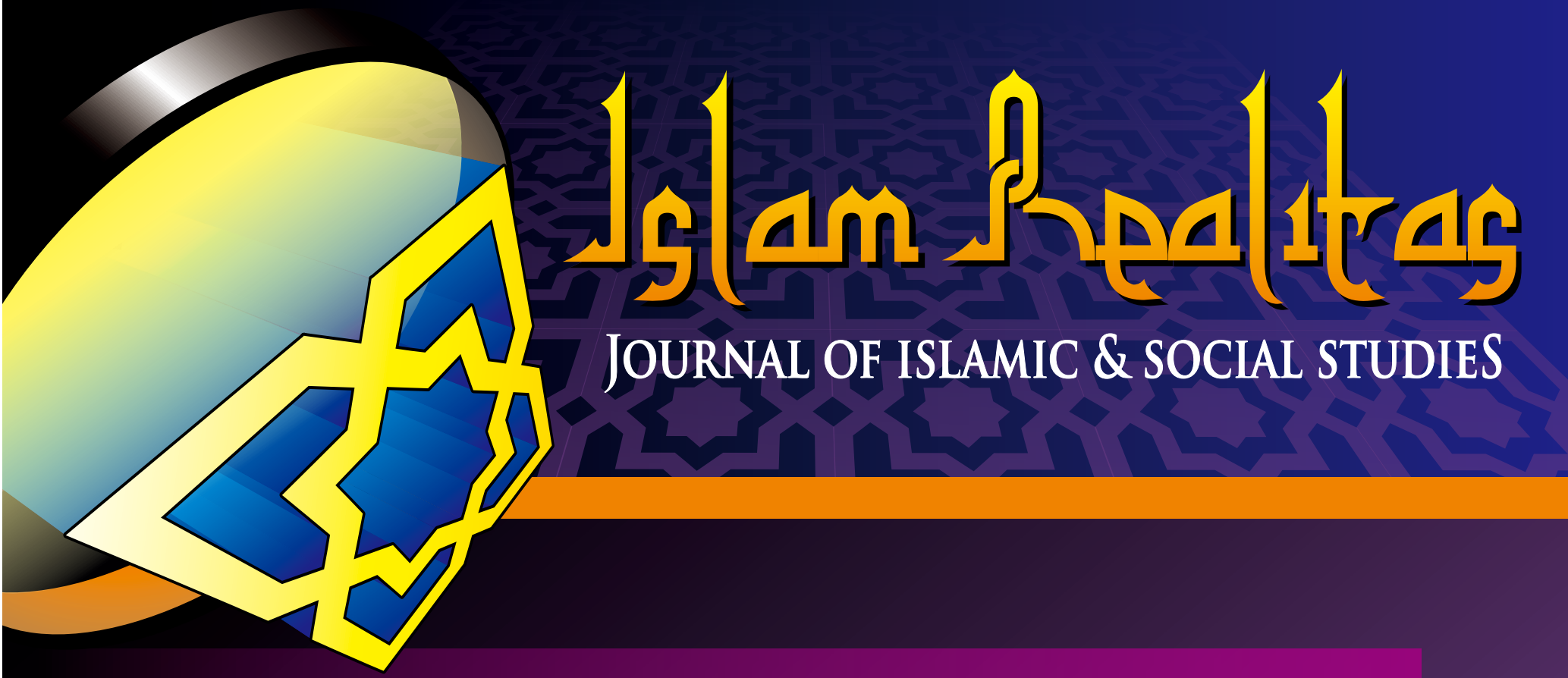

Identitas: Konstruksi Sosial dan Kekuasaan Novi Hendri, Endrizal

Konvensyen Penghapusan Segala Bentuk Diskriminasi Terhadap Wanita (CEDAW) : Satu Tinjauan Awal Dara Maulini Binti Jalaluddin, Norsaleha Mohd Salleh

Berebut Kuasa Rumah Tuhan : Ekspansi ldeologi Radikal Melalui Masjid di Kota Bekasi Zulfan Taufik

Peran Panitia Pengawas Pemilu (PANWASLU) dalam Menekan Potensi Politik Uang pada Wilayah yang Dikuasai Local Strongmen : Studi pada Pemilihan Kepala Daerah Kota Cimahi Tahun 2017 Arlan Siddha, Witjaksono Revitalisasi Peran Sosial Surau Dagang dalam Pembentukkan Karakter Masyarakat Pasar Tradisional di Padang Pariaman Yusrizal Effendi, Nofri Andy $\mathcal{N}$

Harmony in Diversity : Study on Potential Harmonious Multicultural Society "PANTARA" Regions (PANTI-TAPUS-RAO) Northern Border of West Sumatra Nurfitriani Hayati

Pola Jaringan Guru Murid Syeikh Haji Ali Imran Hasan Pondok Pesantren Nurul Yaqin Ringan-ringan : Tahun 1970-2010 Danil Mahmud Chaniago, Akmaludin Mulis

Konsep Pengelolaan Koperasi Pesantren untuk Kesejahteraan Ekonomi Masyarakat : Telaah Surah Al-hasyr Ayat 7

Fahmi Reza, Riyan Hidayat

\begin{tabular}{|l|l|l|l|l|}
\hline Vol. 4 & No. 1 & Januari - Juni 2018 & Hal : 1 - 102 & $\begin{array}{r}\text { ISSN : 2477-1309 } \\
\text { e-ISSN : 2477-1201 }\end{array}$ \\
\hline
\end{tabular}




\title{
POLA JARINGAN GURU MURID SYEIKH HAJI ALI IMRAN HASAN PONDOK PESANTREN NURUL YAQIN RINGAN-RINGAN: TAHUN 1970-2010
}

\author{
Danil Mahmud Chaniago \\ UIN Imam Bonjol Padang \\ e-mail: danil.mabidch@gmail.com
}

\author{
Akmaludin Mulis \\ UIN Imam Bonjol Padang \\ e-mail:akmaluddin74@gmail.com
}

\begin{abstract}
Dalam sejarah pendidikan Pondok Pesantren, nama Syekh Ali Imran termasuk sebagai salah seorang tokoh yang mempelopori berkembangnya pendidikan Pondok Pesantren di Sumatera Barat yang berawal dari sebuah Surau tempat beibadahnya orang muslim. Syekh Ali Imran lahir pada hari rabu tanggal 30 Juni 1926 dalam kondisi Indonesia belum merdeka, sumbangsinya terhadap sejarah pendidikan Islam terutama pendidikan pondok pesatren di Sumatera Barat sangat banyak, terutama di pondok pesantren yang beliau dirikan yaitu Pondok. Pesantren Nurul Yaqin ringan-ringan yang terletak di Ringan-ringan Pakandangan, padang pariaman Sumatera Barat. Sejarah perlu mencatat bagaimana corak, pola, dan jaringan guru murid Syekh Ali Imran di Pondok. Pesantren Nurul Yaqin sebingga mampu berkembnag dan bertahan sampai saat ini dan hal ini merupakan salah satu bukti kontribusinya terhadap sejarah pendidkian Islam di Sumatera Barat dan Indonesia terutama di pondok pesantren.
\end{abstract}

\section{Keywords:}

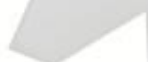

\section{Abstrak}

Dalam sejarah pendidikan Pondok Pesantren, nama Syekh Ali Imran termasuk sebagai salah seorang tokoh yang mempelopori berkembangnya pendidikan Pondok Pesantren di Sumatera Barat yang berawal dari sebuah Surau tempat beibadahnya orang muslim. Syekh Ali Imran lahir pada hari rabu tanggal 30 Juni 1926 dalam kondisi Indonesia belum merdeka, sumbangsinya terhadap sejarah pendidikan Islam terutama pendidikan pondok pesatren di Sumatera Barat sangat banyak, terutama di pondok pesantren yang beliau dirikan yaitu Pondok Pesantren Nurul Yaqin ringan-ringan yang terletak di Ringan-ringan Pakandangan, padang pariaman Sumatera Barat. Sejarah perlu mencatat bagaimana corak, pola, dan jaringan guru murid Syekh Ali Imran di Pondok Pesantren Nurul Yaqin sehingga mampu berkembnag dan bertahan sampai saat ini dan hal ini merupakan salah satu bukti kontribusinya terhadap sejarah pendidkian Islam di Sumatera Barat dan Indonesia terutama di pondok pesantren.

Kata Kunci: Pengelolaan Koperasi; Pertumbuhan Ekonomi; Perkembangan Ekonomi; Kesejahteraan Ekonomi.

\section{Kata Kunci:}

\section{Latar Belakang}

Sosok Syekh Ali Imran sebagai ulama tidak bisa dilepaskan dari leluhurnya yang sudah menjadi ulama terkemuka sebelumnya.
Berawal dari silsilah ulama ini Syekh Ali Imran menerima banyak pendidikan keagaman yang kemudian menjadi bekal baginya dalam mendidkan pondok Pesantern Nurul Yaqin. 
Perjanan sosial keagamaan Syekh Ali Imram yang begitu panjang dalam mencari ilmu dan belajar ke berbagai gurunya yang tersebar hampir di seluruh Sumatera Barat, buah dari perjanan ini pulalah yang membuat Syekh Ali Imran tergerak membangun pondok pesantren berawal dari sebuah surau kecil yang melahirkan jaringan guru murid dan masih bertahan hingga saat ini.

Masalah utama yang menjadi pokus kajian ini adalah bagaimana bentuk pola jaringan guru murid yang terdapat di pondok pesantren Nurul Yaqin ringan-ringan yang berkembang hingga saat ini.

Untuk mendapatkan hasil tulisan ini penulis mengunakan metode analisis deskriptif terhadap data-data yang penulis dapatkan dengan menggunakan wawancara dengan beberapa sumber seperti guru-guru yang mengajar di pondok pesantren Nurul Yaqin, para murid dan masyarakat pondok pesantren termasuk teks-teks yang berkaitan dengan bahasan ini.

\section{Hasil dan Pembahasan}

\section{Syekh Ali Imran; Biografi dan Gurunya}

Ali Imran lahir waktu pada subuh pada Rabu tanggal 30 Juni 1926 di Tanjung Aur. Diberi nama Ali Imran karena waktu itu terjadi perdebatan antara ulama Lahore dengan ulama Syattariyah bernama Ali Imran di Pariaman, dan waktu itu Syekh Hasan juga hadir dalam acara debat tersebut. Sekembali dari acara tersebut lahirlah anak Sitti Amarin yang kemudian diberi nama oleh Syekh Hasan dengan nama Ali Imran. ${ }^{1}$

${ }^{1}$ Tahun kelahiran Ali Imran juga bersamaan dengan peristiwa gempa bumi yang menghebohkan di Padangpanjang tahun 1926. Gempa tersebut juga menjadi petunjuk waktu bagi banyak orang di Minangkabau untuk mengingatkan sesuatu peristiwa yang dialami dalam keluarganya. Tahun 1926, juga tahun kelahiran organisasi Islam terbesar di Indonesia, yakni Nahdlatul Ulama yang lahir tepat 31 Januari 1926.
Ali Imran tumbuh dan berkembang seperti anak-anak lainnya. Syeikh Hasan Tk Bagindo, ayah Ali Imran, selain jadi ulama juga seorang petani untuk menutupi kebutuhan keluarga. Dengan didikan diwarnai dengan nuansa Islami, sejak kecil Ali Imran sudah mempunyai cita-cita yang tinggi, lurus dan taat menjalankan ajaran Islam.

Dari silsilah keturunan, Ali Imran terlahir dari rahim yang memiliki darah ulama. Salah satu ulama yang terkemuka di Padang Pariaman pada abad 18, yaitu Syekh Muhammad Amin bin Abdullah. ${ }^{2}$ Muhammad Amin Bin Abdullah lahir pada tahun Senin 1789 dan wafat pada Senin September 1926, dalam usia 137 tahun. ${ }^{3}$ Orang tua laki-lakinya bernama Abdullah, berasal dari Suku Tanjung Toboh Ketek, dan ibunya Pudi Suku Koto, Kampuang Pandan, Pakandangan, Kabupaten Padang Pariaman. Muhammad Amin lebih dikenal dengan nama Muhammad Aminullah atau Syeikh Mato Aia.

Aminullah lahir dari pasangan Abdullah dan Pudi. Adik Aminullah satu-satunya perempuan bernama Mayang Sani. Dari Mayang Sani, Aminullah memiliki 6 orang keponakan. Masing-masing Saripah, Anjang Duata, Piak Banyak, Madinah, Muhammad Syarif dan Tibarahi. Artinya Mayang Sani memiliki 4 orang anak perempuan dan 2 orang anak laki-laki.

Kemudian dari Piak Banyak melahirkan 2 orang perempuan dan 2 orang laki-laki.

${ }^{2}$ Sumber lain menyebutkan, nama Muhammad Amin bin Abdullah. Sebagaimana disebutkan dalam Nazam Rihlatul Minangkabawi. Nazam ini merupakan kisah perjalanan Muhammad Amin bin Abdullah ke Mekah dan kembali ke kampung hamannya. Wawancara dengan Awalluddin Tk Mudo, Jumat, 7 Juli 2017 di Komplek Makam Syeikh Mato Aia Sarang Gagak.

3 Bahan-bahan dalam bagian ini merupakan wawancara penulis dengan salah seorang keturunan Syekh Muhammad Aminullah Tuanku Mudo Mato Aie, Awaluddin Datuak Pamuncak Majolelo, Sabtu, 6 Agustus 2017 di kediamannya, kawasan Tapakih, Nagari Sintuak Kecamatan Sintoga, Kabupaten Padangpariaman. 
Masing-masing Miatin, Kasuma, Danan, dan Marin ${ }^{4}$.

Kemudian Marin, dikarunia 5 anak yaitu Ali Imran, Muslim Rasyid, Rosmani (Simanih), Idris dan Misratul Maaz (Simai).

Di antara guru Aminullah adalah Inyiak Ungku Surau Baukia di Parit Malintang, Kecamatan Enam Lingkung, Syeikh Abdurrahman Lubuak Ipuah, Uwai Limapuluh. Selain Syekh Hasan Tuanku Bagindo (ayah Ali Imran) murid-muridSyeikh Mato Aia yang terkenal antara lain Syekh Parabek, Syekh Cacang Tiku Kabupaten Agam, Buya Ungku Saliah Keramat Sungai Sariak, Kabupaten Padang Pariaman dan Buya Abdul Karim Amarullah (HAKA) atau Inyiak De Er.

\section{Pendidikan dan Jaringan Guru Syekh Ali Imran Hasan}

Pada tahun 1935 Ali Imran dibawa ayahnya Pakiah Hasan ke Sitanang Lubuk Basung. Di sana Ali Imran sekolah rakyat hingga kelas 5. Ia tamat kelas 5 tahun 1940. Kemudian ayahnya pindah ke Tapian Kandih, Palembayan Matua Kabupaten Agam. Di sana Ali Imran turut membangun Sekolah Dasar, sekaligus mengajarnya. Meski baru tamat kelas 5, tapi sudah bisa mengajar. Namun Ali Imran tidak lama di Tapian Kandih, hanya setahun, kemudian pulang.

Tahun 1941 Ali Imran pulang bersama ayahnya ke Ringan-ringan dan melanjutkan pendidikan di Surau Tangah Sawah bersama Syekh Hasan selama tiga tahun. Sekali-sekali juga belajar kepada mamaknya Mukhtar Tuanku Mato Aia di Pakandangan, hal ini sesuai dengan perintah ayah beliau agar Ali Imran juga belajar kepada mamaknya. Sebenarnya Ali Imran beberapa saat dikampuang sudah ingin untuk melanjutkan pendidikan ketempat lain, tapi karena

\footnotetext{
4 Buya Syekh Ali Imran Hasan sering menyapa dengan Uniang Marin. Sedangkan namanya bagi Buya Syekh Ali Imran adalah Siti Amarin.
}

kerinduan terhadap orang tua dan ingin membantu orang tua dirumah akhirnya diputuskan untuk bertahan beberapa tahun di kampung.

Setelah tiga tahun dikampuang ternyata keinginan tersebut tidak dapat ditahan dan akhirnya atas izin orang tua dan diputuskannya untuk belajar ketempat Syekh Ibrahim Hajji di Koto Baru Kec. X Koto Tanah Datar tahun 1944. Syekh Ibrahim Haji adalah sahabat Syekh Hasan ketika sama belajar di Surau Syekh Muhammad Yatim mudiak Padang.

Suasana mengaji di Koto Baru sedikit berbeda dengan biasanya karena pengaruh penjajahan Jepang, pada hari tertentu harus ikut gotong royong. Setahun Ali Imran disini akhirnya Syekh Ibrahim pindah mengajar ke Kota Padang. Ali Imran tidak mengikutinya ke Padang. Tetapi meneruskan ke Mungo Lima Puluh Kota belajar kepada Syekh Syahidan Syarbaini selama tiga tahun, sampai tahun 1946. Ali Imran memperdalam ilmu alat (nabwu dan sharaf).

Setelah tiga tahun di Mungo Ali Imran melanjutkan mengaji ke Madrasah Tarbiyah Islamiyah Tiakar Payakumbuh dari tahun 1946 hingga 1949. Di Tiakar Ali Imran berguru pada Syekh Ibrahim Harun. Di sini ia belajar kitab, bahasa Arab dan cabang-cabang ilmunya.

Di Tiakar, Ali Imran belajar selama empat tahun. Setelah belajar selama setahun Ali Imran dipercaya Ibrahim Harun membina sebuah Suran menjadi guru tuo ${ }^{5}$. Di Surau tersebut ada 13 orang dari Lintau yang diajarkan Ali Imran. Ibrahim Harun sendiri berasal dari Lintau. Murid tersebut dipercayakan kepada Ali Imran agar dapat belajar mengaji dengan baik. Ini pertama kali Ali Imran dipercaya mengajar oleh gurunya. Anak-anak dari Lintau tersebut diserahkan kepada Ali Imran untuk dididik dan diajarkan mengaji. Dari sini Ali Imran mulai

${ }^{5}$ Guru tuo $=$ kakak asuh, guru asrama, sebutan guru di kalangan pondok Pesantrendi Sumatera Barat. 
menunjukkan kemampuan mengajar. Kepercayaan mengajar juga menjadi taruhan Ali Imran menunjukkan dirinya. Dengan penuh keyakinan, kepiawaian dan pengalaman yang sudah diperoleh selama mengaji yang berpindah-pindah, Ali Imran berusaha sekuat kemampuan mendidik anak-anak tersebut.

Pada tahun 1949, dari Tiakar Payakumbuh, kemudian Ali Imran melanjutkan pendidikannya ke Padang Japang selama setahun sampai tahun 1950 di Pondok Pesantren Darul Funun Abasiyah kepada Syekh H. Nasaruddin Taha, untuk belajar bahasa Belanda dan Bahasa Inggris . pada tahun 1950 Ali Imran pindah dari Padang Japang ke Padang Panjang. Memang tidak lama di Padang Japang, tapi ia dapat menyelesaikan pendidikan bahasa Inggris dan Bahasa Belanda dengan baik. Kepindahan Ali Imran melanjutkan pendidikan ke Padang Panjang tepatnya di Malalo, Tanah Datar, di pinggir danau Singkarak disebabkan beberapa masalah, di antaranya seperti, sukses mengaji dan mulai mengajar santri, merupakan hal yang menggembirakan bagi Ali Imran. Namun santri yang diajar tidak satu pun dari kampung halamannya, Padang Pariaman. Ali Imran ingin berbagi ilmu dengan santri yang berasal dari Padang Pariaman. Ali Imran mencari informasi di mana Pesantren yang santrinya banyak berasal dari Padang Pariaman.

Akhirnya Ali Imran memutuskan melanjutkan pendidikan ke Madrasah Tarbiyah Islamiyah Malalo. Di Malalo, Ali Imran tidak saja belajar kitab seperti sebelumnya, tapi sudah dipercaya mengajar di lokal. Di Malalo ini Ali Imran mulai menampakkan bakatnya sebagai guru, ulama, sekaligus pendakwah yang disenangi jama'ah. Mula-mula dipercaya mengajar santri junior, secara bertahap sampai mengajar di kelas tinggi, dan kemudian dipercaya Pimpinan Pesantren Syekh Zakariya Labai Sati Malalo menggantikan dirinya pada momen tertentu sampai memberikan pengajian rutin kepada jama'ah di Malalo.
Dari tahun pertama di Malalo, Ali Imran sudah mulai mengajar di kelas, seperti kelas 3 selama setahun. Kemudian mengajar di kelas 4 selama 2 tahun. Kemampuan mengajar Ali Imran terus meningkat dan menyenangkan santri. Sehingga Pimpinan Madrasah Tarbiyah Islamiyah Syekh Zakariya Labai Sati Malalo ${ }^{6}$ terus memberikan kepercayaan mengajar ke tingkat yang lebih tinggi. Dua tahun berikutnya dipercaya mengajar di kelas 5 selama 2 tahun. Kemudian mengajar kelas 6 selama 2 tahun. Terakhir mengajar di kelas 7 selama tiga tahun. Di kelas terakhir ini Ali Imran paling lama mengajar. Secara keseluruhan Ali Imran mengajar di Pesantren Malalo selama 10 tahun, yakni dari tahun 1950 hingga 1960. Ketika mengajar di Malalo ini terjadi peristiwa Pemerintahan Revolusioner Republik Indonesia (PRRI).

Ketika tentara Angkatan Perang Republik Indonesia (APRI) menyerang tentara Pemerintahan Revolusioner Republik Indonesia (PRRI) sampai di Ombilin, tembakan-tembakan diarahkan ke Malalo. Ombilin yang berada di seberang Danau Singkarak, menjadikan Malalo salah satu sasaran. Karena APRI menduga tentara PRRI banyak yang melarikan ke hutan bukit yang berada di Malalo.

Pada tahun 1960 Syekh Ali Imran pulang ke kampung halamannya. 1960 Ali Imran mulai mengajar dan membantu Syekh Hasan mengembangkan ajaran Islam di Pakandangan. Setelah beberapa saat dikampung Ali Imran melanjutkan belajar sambil mengajar kepada Tuanku Salif Kiramat, kepada beliau Ali Imran belajar ilmu obat-obatan dan tasawuf (Kaji Cuknik).

Kalau diurut dari pertama belajar ilmu agama guru Ali Imran berjumlah tujuh orang,

${ }^{6}$ Syekh Zakariya Labai Sati Malalo berguru kepada Syekh Ja' far. Syekh Ja'far berguru kepada Syekh H.Abdurrahman Bin Paduko Laksmano (Lahir 1240 H, w. 1333 H, bermakam di Kampar, Propinsi Riau).

7 Bainar (76), wawancara, Minggu, 18 September 2017 di kediamannya, Padang Laweh, Malalo. 
dimulai dari Syekh Hasan Tuanku Bagindo, Syekh Ibrahim Haji, Syekh Syahidan Sarbaini, Syekh Ibrahim Bomban, Syekh Muhammad Thaha, Syekh Zakaria Labai Sati, hingga Buya Tuanku Salif Kiramaik. Secara garis besar dikelompokkan guru Syekh Ali Imran berasal dari aliran tarekat yang berbeda, yaitu Syekh Hasan Tuanku Bagindo, Syekh Ibrahim Hajji, dan Buya Tuanku Salif Kiramaik adalah ulama aliran tarekat Syattariyah, yaitu tarekat yang dibawa oleh Syekh Burhanuddin Ulakan dan dipelajarinya kepada Abdurrauf Singkil di Aceh. Sementara Syekh Syahidan Sarbaini, Syekh Ibrahim Bomban, dan Syekh Zakaria Labai Sati adalah ulama dengan terikat Naqsabandiyah, yaitu tarekat yang lahir di Bukhara pada akhir abad ke 14 didirikan oleh Muhammad ibn Baha al-Din al-Uwaysi alBukhari (717-791H/1318-1389M), kemudian yang membawa ke Sumatera Barat adalah Syekh Abdurrahman Khalidi Sungai Tarab, (1889), Syekh Ibrahim Kumpulan, Syeikh Khatib Ali Padang, dan Syekh Muhammad Said Bonjol. Keempat orang ini langsung mendapat ijazah dari Syekh Sulaiman al-Zuhdi di Jabal Qubays. ${ }^{8}$

Di antara kedua kelompok guru Ali Imran kalau mengenai kitab yang diajarkan atau secara keilmuan tidak ada masalah dalam artian sama di antara keduanya. Selanjutnya akan dilihat ranji keguruan Syekh Ali Imran baik melalui keilmuan maupun secara tarekat. Pengelompokkan di antara keduanya sebenarnya tidak bisa dilakukan secara eksplisit karena antara guru tarekat dan guru secara keilmuan tidaklah bisa dipisahkan, seperti Syekh Ibrahim Harun, disatu sisi dia adalah guru tarekat karena di Suraunya memiliki Surau suluk, Sementara dia juga mengajarkan ilmu keagamaan non tarekat seperti ilmu tafsir, Fiqh nabwu, dan lain-lain. Hal itu juga ada pada Pesantren Madrasah Tarbiyah Islamiyah

8 Sofyan Hadi, Tarekat Naqsabandiyah Khidiyah di Minangkabau (Jurnal Manassa Manuskripta Vol 1 No 2, 2011)
Malalo yang di kelola Syekh Zakaria Labai Sati. Hal yang sama juga terdapat di Surau Tangah Sawah yang dibina oleh Syekh Hasan Tuanku Bagindo, di mana pada hari tertentu belajar Tasamuf Syattariyah. Jadi sebenarnya kalau kita melihat tentu secara inplisit yaitu melalui afiliasi jaringan keguruan masing-masing guru keatas, apakah guru-guru Syekh Ali Imran tersebut cendrung belajar kepada guru kepada kelompok yang mana dan tarekat apa yang dikembangkan di Pesantren tersebut, walaupun sebenarnya guru tersebut mampu mengajarkan beberapa jenis tarekat, seperti yang dilakukan Syekh Uwai Limo Puluah, disatu sisi beliau pernah belajar kepada Syekh Abdullah Suran Gadang yang bertarekat Naqsabandiyah $^{9}$, dan setelah itu belajar kepada Syekh Abdurrahman Lubuk Ipuah yang mengamalkan tarekat Syattariyah, kemudian dalam mengajar muridnya lebih cendrung mengajarkan tarekat Syattariyah, seperti ilmu yang diterima Syekh Muhammad Amin bin Abdullah (Syekh Mato Aia) Sarang Gagak. ${ }^{10}$ $\mathrm{Hal}$ ini juga seiring dengan pendapat Azra yang mengatakan bahwa mereka beragam satu sama lain bukan hanya dalam hal tempat asal dan etnisitas, tetapi juga dalam hal mazhab dan afiliasi tarekat. Sementara seorang guru merupakan pengikut mazhab Hanafi, muridnya bisa jadi pengikut mazhab Syafi'i. Sementara seorang guru adalah sufi Syathariyah, muridnya bisa jadi pengikut tarekat Naqsabandiyah. Meski ada perbedaanperbedaan semacam ini, ulama dalam jaringan memiliki kecendrungan umum kearah reformisme Islam. ${ }^{11}$

tarekat Syattariyah yang menjadi payung aktifitas keagamaan Surau Nurul Yaqin dipercaya bersumber dari Syekh Burhanuddin Ulakan. Pembicaraan tentang jaringan

\footnotetext{
9 Apria Putra Ulama-ulama Luak Nan Bungsu. Padang: Minangkabau Press,2011.h.200

${ }^{10}$ Wawancara dengan Awaluddin Tk Mudo tanggal 16 Maret 2017. Jam 14.00 di Surau Mato Aia Sarang Gagak.

${ }^{11}$ LocCit,Azra, h.116
} 
keilmuan Syathariyah dari batas Syekh Burhanuddin dan guru-gurunya hingga ke Abdurrauf al-Sinkili sudah dibicarakan dalam beberapa sumber bacaan penting, ${ }^{12}$ karena itu tidak disinggung dalam tulisan ini. Penekanan pembicaraan dalam bagian ini lebih terarah pada riwayat Syekh Ali Imran sendiri dalam menuntut ilmu. Adapun bila dalam pembahasan diperoleh mata rantai dari silsilah guru-gurunya, maka hal itu tidak lebih dari sebuah akses dari kerangka penulisan riwayat hidup beliau, karena bagai manapun dalam tradisi keilmuan tarekat Syathariyah membentuk silsilah yang menjelaskan perjalanan seorang murid dalam memburu pengetahuan keagamaan.

Terkait dengan hal itu, satu-satunya petunjuk tertulis mengenai silsilah keilmuan Syekh Ali Imran dalam mata rantai guru dan murid dalam tradisi tarekat Syathariyah adalah naskah yang yang dibacakan dalam Bai'at di Nurul Yaqin, ${ }^{13}$. Guru pertama yang didatangi oleh Syekh Ali Imran adalah ayah beliau sendiri yaitu Syekh Hasan Tuanku Bagindo. Setelah belajar kepada Syekh Hasan Tuanku Bagindo selama 9 tahun (1935-1944M). Selang beberapa waktu kemudian ia pergi pula ke nagari Koto Baru Padang Panjang guna menuntut ilmu kepada Syekh Ibrahim Hajji. Di sini pun perjalanan keilmuan Syekh Ali Imranhanya satu tahun. Sama seperti di Surau Tangah Sawah, ia masih belum puas untuk mencari kaji. Atas alasan ini ia meminta izin kepada Syekh Ibrahim Hajji untuk mencari pengalaman baru di Mungo di bawah bimbingan Syekh Syahidan Sarbaini. Di Surau Syekh Syahidan Sarbaini sebenarnya secara tarekat tidak berhubungan karena tarekat Seikh

12 Yang terpenting antara lain Azyumardi Azra, Jaringan Ulama Timur Tegah dan Kepulauan Nusantara Abad XVII \& XVIII, Akar Pembaruan Islam di Indonesia, edisi revisi, Kencana, Jakarta:2007, terutama haman 255-257; Oman Fathurahman, Tarikat Shattariyyah di Dunia Melayu-Indonesia, terutama bagian apendiks 3: Silsilah Tarekat Syattariyyah.

13 Catatan Harian Syeikh Muda Muhammad Rais Tuanku Labai nan Basa.
Syahidan Sarbaini adalah Naqsabandiyah. selanjutnyaSyekh Ali Imran kembali mendalami tarekat Syattariyah setelah kembali dari Malalo (1960) yaitu dengan belajar kepada Syekh Hasan Tuanku Bagindo. Dalam waktu relatif singkat semua ilmu yang diajarkan dapat dikuasai dengan baik oleh Syekh Ali Imran. Atas perkembangan yang pesat itu, dan setelah menerima sepenuhnya ilmu yang diberikan oleh gurunya, Syekh Hasan Tuanku Bagindo.Sejak saat itu (1963) Syekh Ali Imran telah dipercaya oleh Syekh Hasan untuk menggantikannya dalam hal pengajaran tarekat. Selanjutnya Syekh Ali Imran juga berinisiatif untuk belajar kepada Buya Tuanku Salif Kiramaik,belajar lebih lanjut kepada buya Angku Salif Kiramaik di Sungai Sariak Padang Pariaman, guna memperoleh pengetahuan lebih dalam.

Hubungan silsilah keilmuan dan tarekat Syattariyah Syekh Hasan Tuanku Bagindo adalah kepada Syekh Malin Bandaro Koto Tujuah, Syekh Malin Bandaro Koto Tujuah kepada Syekh Ismail Padang gantiang, Syekh Ismail Padang Gantiang kepada Syekh Muhammad Saleh Talawi, Syekh Muhammad Saleh Talawi kepada Syekh Cupak, Syekh Cupak Kepada Kadi Padang Gantiang (Dt. Maruhun Panjang Padang Gantiang), Kadi Padang Gantiang kepada Syekh Burhanuddin. ${ }^{14}$

Sementara guru Syekh Hasan yang lain adalah Syekh Muhammad Amin (Mato Aia) yang belajar kepada Syekh Malalo Limo Puluah (Uwai Limo Puluah), Syekh Malalo Limo Puluah kepada Syekh Abdurrahman Lubuak Ipuah, Syekh Abdurrahman Lubuak Ipuah kepada Syekh Jangguik Itam Lubuak, Syekh Jangguik Itam Lubuak kepada Syekh Burhanuddin. ${ }^{15}$ Sementara guru yang lain dari Syekh Malalo Limo Puluah adalah Syekh Abdullah Surau Gadang di Lima Puluh Kota dan bertarekat Naqsabandiyah. Untuk ranji

14 Catatan Harian Syeikh Muda Muhaamad Rais Tuanku Labai Nan Basa

${ }^{15}$ LocCit, Oman, Lampiran 3 
keguruannya di Surau Gadang Kabupaten Lima Puluh Kota, Syekh Abdullah kepada Beliau Surau Durian. ${ }^{16}$ Data ranji keguruan Syekh Malalo Limo Puluah melalui Syekh Abdullah hanya sampai ke Beliau Surau Durian yang penulis temukan.

Dari guru Syekh Ali Imran yang lain yang bertarekat Syattariyah adalah Syekh Ibrahim Haji Koto Baru Padang Panjang, di mana Syekh Ibrahim Hajji belajar kepada Syekh Muhammad Yatim di Surau Luhur Kalampaian Ampalu Tinggi, Syekh Mhd Yatim belajar kepada Syekh Talawi, Syekh Talawi kepada Syekh Sunda Katapiang, Syekh Sunda Katapiang kepada Syekh Labai, Syekh Labai kepada Syekh Oesman, Syekh Oesman kepada Syekh Paraman Siangan Pandai Sikek, Syekh Paraman Siangan kepada Syekh Burhanuddin. ${ }^{17}$

Dari Tuanku Salif Kiramaik, Syekh Ali Imran mempunyai ranji bahwa Tuanku Salif belajar kepada Syekh Mato Aia (Syekh Muhammad Amin), Syekh Mato Aia belajar kepada Uwai Limo Puluah, Uwai Limo Puluh kepada Syekh Abdurrahman Lubuk Ipuh, Syekh Abdurrahman kepada Syekh Jangguk Itam, Syekh Jangguik Itam kepada Syekh Burhanuddin. ${ }^{18}$ Dari guru yang lain Tuanku Salif Kiramaik mempunyai guru Angku Ampalu Tinggi, Angku Ampalu Tinggi kepada Syekh Talawi Padang Gantiang, Syekh Talawi Padang Gantiang kepada Syekh Sultan AlKisa'I Ibn Habibullah, Syekh Sultan Al-Kisa'I kepada Syekh Abdurrahman Ulakan, Syekh Abdurrahman Ulakan kepada Syekh Burhanuddin. ${ }^{19}$

Dari semua guru tarekat Syattariyah dan keilmuan dari tiga orang guru itu bermuara kepada Syekh Burhanuddin Ulakan yang

${ }^{16}$ LocCit, Apria Putra, h. 205

${ }_{17}$ Amiruddin, Berjuang Tanpa Pamrih, (Pdg Pariaman: PEMDA Pdg Pariaman,2005) h. 46

18 Wawancara dengan Awaluddin Tuanku Mudo tanggal 16 Maret 2017 di Surau Sarang Gagak pukul 14.00 WIB

${ }^{19}$ LocCit, Oman, Lampiran 3 merupakan murid dari Syekh Abdurrauf Singkil di Aceh.

Sementara kalau dilihat dari ranji di tarekat Naqsabandiyah atau yang berguru kepada ulama yang bertarekat naqsabandi maka dapat dilihat sebagai berikut. Guru Syekh Ali Imran yang mengamalkan tariqat naqsabandi di antaranya Syekh Syahidan Sarbaini, beliau adalah ulama yang mengembangkan kajinya di Mungo Bawah Kabupaten Lima Puluh Kota. Dari ranji keguruan bahwa beliau pernah belajar kepada Syekh Rasyid Taher, Syekh Rasyid Taher kepada Syekh Sungayang, Syekh Sungayang kepada Syekh Sulaiman Arrasuli, Syekh Sulaiman Arrasuli kepada Syekh Abdullah (Beliau Halaban), Syekh Abdullah kepada Syekh Abdurrahman Batu Hampa, Syekh Abdurrahman Batuhampa kepada Syekh Abdurrahman Khalidi (Beliau Galo Gandang). Sementara ranji keguruan Syekh Rasyid Taher yang lain adalah dari Syekh Mhd Saad Surau Baru, Syekh Mhd Sa'ad kepada Syekh Abu Bakar Tabiang Pulai, Syekh Abu Bakar Tabiang Pulai kepada Syekh Mhd Jamil Tungka, Syekh Mhd Jamil Tungka kepada Syekh Mhd Taher Barulak, Syekh Mhd Taher Barulak kepada Syekh Sulaiman, Syekh Sulaiman kepada Ismail, Syeikh Ismail kepada Syekh Abdul Jabal, Syekh Abd Jabal kepada Syekh Khalid Naqsabandi. Dari ranji Syekh Syahidan Sarbaini dengan Syekh Rasyid Taher melalui gurunya Tuanku Mudo Karuang Sicincin dapat dilihat bahwa Tuanku Mudo Karuang Sicincin berguru kepada Syekh Abdullah Surau Gadang, Syekh Abdullah kepada Beliau Surau Durian. ${ }^{20}$

Melalui ranji Syekh Abdullah, maka bertemu ranji guru murid Syekh Syahidan Sarbaini dengan dengan Tuanku Salif Kiramaik di Syekh Abdullah Surau Gadang. Artinya Tuanku Mudo Karuang dengan Uwai Limo Puluah satu guru yaitu Syekh Abdullah Surau Gadang.

$$
{ }^{20} \text { LocCit, Apria Putra, h. } 208
$$


Dari guru Syekh Ali Imran yang ke empat yaitu Syekh Ibrahim Harun (Baliau Bomban) Tiaka, dapat dilihat bahwa Syekh Ibrahim Harun belajar kepada Syekh Abdullah Halaban, Syekh Abdullah Halaban kepada Syekh Abd Rahman Batuhampa, Syekh Abdurrahman Batuhampa kepada Syekh Abdurrahman Khalidi Galo Gandang. Ranji Syekh Ibrahim Harun Bertemu dengan ranji Syekh Syahidan Sarbini di Syekh Abdurrahman Batuhampa melalui Syekh Sungayang. Sementara dari ranji guru Syekh Abdullah Halaban (guru Syekh Ibrahim Harun) yang lain yaitu Syekh Thaha Limbukan, dari Syekh Thaha kepada Syekh Mhd Saleh Pdg Kandih, Syekh Mhd Saleh kepada Syekh Karim bin Fathani, Syekh Karim kepada Syekh Sulaiman Affandi, Syekh Sulaiman Affandi kepada Syekh Aliyuddin, Syekh Aliyuddin kepada Syekh Khalid Naqsabandi. Dari ranji Syekh Abdullah yang belajar kepada Syekh Thaha Limbukan maka bertemu juga ranji keguruannya dengan Syekh Sahidan Sarbaini di Syekh Khalid Naqsabandi.

Dari guru Syekh Ali Imran yang ke lima yaitu Syekh Zakaria Labai Sati Malalo, dapat dilihat bahwa Syekh Zakaria Labai Sati belajar kepada Syekh Mhd Jamil Jaho, Syekh Mhd Jamil Jaho kepada Syekh Abdullah Halaban, Syekh Abdullah Halaban.....( seperti yang telah diterangkan pada ranji guru Syekh Ibrahim Harun terhadap ranjinya, karena Syekh Abdullah yang dimaksud adalah sama). ${ }^{21}$

Dari tiga guru Syekh Ali Imran yang berafiliasi kepada tarekat Naqsabandi seperti Syekh Syahidan Sarbaini, Syekh Ibrahim Harun, dan Syekh Zakaria Labai Sati, ketiganya memilki ranji keguruan yang hampir sama. Rata-rata guru mereka belajar ditempat yang sama yaitu guru yang berafiliasi ke Syekh Abdurrahman Batuhampa. Pertemuan ranji mereka yang lain adalah di Syekh Khalid Naqsabandi. Sementara dari dua aliran tarekat

${ }^{21}$ LocCit,Apria Putra, h. 205 yaitu tareqat naqsabandi dan Syattari pertemuan guru Syekh Ali Imran adalah antara melalui Syekh Hasan Tuanku Bagindo, dan Tuanku Salif Kiramaik melaui Syekh Muhammad Amin (Mato Aia) dengan Syekh Syahidan Sarbaini melaluiTuanku Mudo Karuang Sicincin pada Syekh Abdulah Surau Gadang.

Dari semua guru Syekh Ali Imran hanya enam guru yang rutin di Ziarabinya, di antaranya Tuanku Salif Kiramaik setiap bulan Rajab, Syekh Hasan Tuanku Bagindo bulan Sya'ban, guru Syekh Ibrahim Hajji (Syekh Muhammad Yatim) bulan Sya'ban, Syekh Ibrahim Harun, Syekh Syahidn Syarbaini bulan Syafar, Syekh Zakaria Labai Sati bulan Muharram. Hal ini seperti tradisi yang biasa dilakukan oleh tarekat Syattariyah, yaitu menziarahi ulama. Hal ini merupakan unsur penting dalam penentuan mata rantai keilmuan seorang murid.

Keilmuan masing-masing guru Ali Imran tetap ada seperti ilmu Nabwu dan saraf diterima dari Syekh Sahidan Sarbaini. Ilmu tafsir, Fiqh, badi', bayan, ma'ani, diterima dari Baliau Bomban dan Syekh Zakaria Labai Sati, dan ilmu tasawnf naqsabandi diterima dari Syekh Zakaria Labai Sati, walaupun tarekat ini tidak dikembangkan oleh Syekh Ali Imran . Untuk tarekat Syattariyah Syekh Ali imran memperolehnya dari Syekh Hasan Tuanku Bagindo, Syekh Ibrahim Hajji Koto Baru, dan Tuanku Salif Kiramaik.

Selain ziarah merupakan menegaskan silsilah keilmuan, terutama tasauf, juga mempertegas bahwa ajaran-ajaran tasauf yang diterima oleh Syekh Ali Imran tidak berbeda dengan karakter tasauf yang dibawa oleh Syekh Burhanuddin Ulakan.

Faktor penguasaan Syekh Ali Imran terhadap materi-materi keilmuan yang populer diajarkan dalam tradisi tarekat Syattariyah ini mengharumkan nama beliau. Dengan nama besar seperti itu, Syekh Ali Imran banyak 
dikunjungi oleh murid-murid dari berbagai daerah.

Hingga sekarang pondok Pesantren Nurul Yaqin masih eksis dalam dua tingkatan: Madrasah Tsanawiyah dan Madrasah 'Aliyah. Atas usaha Syekh Ali Imran, ajaran-ajaran tarekat Syattariyah ajaran-ajaran tradisional terus dilestarikan. Ajaran-ajaran Tasawuf masih tetap eksis hingga saat ini, disampaikan melalui pengajian-pengajian pada majelis-majelis tertentu di Surau-Surau berbasis tarekat Syattariyah, di Padang Pariaman dan sekitarnya. Sesuai dengan perkembangan terakhir, berdasarkan aktifitas Pondok Pesantren Nurul Yaqin dan Surau-Surau yang didirikan oleh pengikut-pengikut beliau, saat ini ajaran tarekat Syattariyah masih dilestarikan di Surau tersebut oleh murid-murid Syekh Ali Imran, yang menerima Bai'at dari Syekh Ali Imran, di Pesantren Nurul Yaqin.

\section{Pola Jaringan Guru Murid Pondok Pesantren \\ Nurul Yaqin.}

Secara lebih spesifik, jaringan guru dan murid di Pesantren erat kaitannya dengan pewarisan ilmu keagamaan. kata "jaringan" pada aspek tertentu mengandung penegasan adanya transmisi ilmu keagamaan dari generasi ke regenerasi.

Jaringan guru murid diperkenalkan oleh Azyumardi Azra dalam bukunya Jaringan Intelektual Ulama Timur Tengah dengan Kepulauan Nusantara Abad XVI dan Abad XVII. Setelah karyanya yang berjudul Jaringan Ulama ini diterbikan, istilah ini sebagai sebuah teori keilmuan mulai populer. Ia membatasi, bahwa teori Jaringan Intelektual ini bukanlah membahas teks-teks yang terdapat di dalam buku, melainkan mengkaji perosalan-persoalan orang yang mengalami proses belajar dan mengajar yang mencakup ${ }^{22}$ :

22 Azyumardi Azra, Jaringan Ulama Timur Tegah dan Kepulauan Nusantara Abad XVII \& XVIII, Akar Pembaruan Islam di Indonesia, edisi revisi, Kencana, Jakarta:2007, h. 255-257 a. Sejarah proses belajar

b. Tempat-tempat belajar

c. Penyusunan jaringan intelektual keilmuan

d. Penyusunan daftar ilmu yang dikembangkan

e. Tradisi dan adab yang dibiasakan di lembaga pendidikan

Bersamaan dengan proses keilmuan Islam di Pondok Pesantren Nurul Yaqin Pakandangan pada tahun 1970-2010, Pesantren ini digunakan oleh para ulama dan murid-muridnya sebagai pusat jaringan keilmuan. Di Pesantren inilah para guru (ulama) menyebarluaskan gagasan-gagasan keagamaan, terutama yang terkait dengan ajaran-ajaran mendasar Islam. Dalam konteks demikian, Pesantren adalah wujud nyata dan menjadi media pembelajaran yang sangat efektif, terutama dilihat dari proses Islamisasi di Sumatera Barat. Berkaitan dengan ini, harus diakui bahwa sebagai institusi yang mengemban tugas pendidikan sekaligus penyebaran ajaran-ajaran keIslaman, yang sumber-sumber ajarannya ditulis dengan bahasa Arab, Pesantren beserta orang-orang yang mengajar dan belajar di dalamnya adalah mereka yang terlebih dahulu mahir ilmu agama, dalam hal ini agama Islam tradisional.

Dalam hal ini, Pesantren berbasis ilmu agama dan tarekat Syattariyah yang melaksanakan pengajaran dan pewarisan ilmu keagamaan pada gilirannya mengemban proses pewarisan yang menimbulkan jaringan keilmuan ini. Fathurahman menegaskan bahwa, Tarekat Syattariyah di nusantara dengan persebaran dapat menjelaskan matarantai keilmuan dan saling keterhubungan guru dan murid komunitas ini. ${ }^{23}$ dalam konteks itu, Pesantren Nurul Yaqin yang berafiliasi kepada tarekat Syattariyah tergolong produktif melahirkan alumni. Pada saat sekarang tingkat produktifitas Pondok Pesantren dalam

23 Oman Fathurrahman, Tarekat Syattariyah di Minangkabau, (Jakarta:Prenada Media Group, 2008), h.7 
melahirkan jaringan guru murid masih terlihat aktif. ${ }^{24}$

Adapun santri yang menyematkan gelar tuankunya diangkat menjadi tuanku dihitung dari tamatan tahun 1970, karena pendataan yang telah dibukukan baru dimulai tahun 1970 . Berdasarkan buku catatan alumni tersebut mereka yang menyematkan gelar tuankunya pertama kali sebanyak empat orang, di antaranya Syahril Tuanku Mudo dari Malalo bersama tiga temannya yang lain, Zubir Tuanku Sutan dari Kayu Tanam, Syamsir Alam Tuanku Malin Bagindo dari Kasang, dan Tarmizi Tuanku Pakiah Majolelo dari Malalo dinyatakan tamat di Pesantren Nurul Yaqin Ringan-Ringan. Keempatnya dapat dikatakan lulusan pertama dari Nurul Yaqin.

Setahun kemudian, pada tahun 1971, kawan-kawan Syahril yang lain berhasil menyematkan gelar tuankunya. Tahun ini banyak yang dinyatakan lulus, hampir 95 persen yang mengaji bersama Syahril dinyatakan lulus sebanyak lima orang di antaranya Musrial Tuanku Pakiah Kayo dari Malalo, Firdaus Tuanku Rajo Mangkuto dari Lintau, Harmaini Tuanku Panduko Sati dari Malalo, Nalib Tuanku Malin dari Lintau. Karena sudah banyak yang dinyatakan lulus, diadakan perayaan. Arak-arakan santri yang sudah lulus pun dilakukan dari Ringan-Ringan ke Parik Malintang. Dimulai dari tahun ini perayaan pengangkatan tuanku selalu diadakan arak-arakan ke Parik Malintang dengan diiringi bunyi-bunyian seperti rebana atau drum band.

Tahun 1972 tercatat hanya menyematkan gelar tuankunya sebanyak dua orang yaitu Asroel Tuanku Malin Bungsu dari Lintau, dan Syuryadi Tuanku Mudo dari Koto Baru. Perayaan angkatan 1972 ini juga dilaksanakan pada tahun berikutnya, yaitu seiring dengan tamatan tahun 1973 sebanyak dua orang pula di antaranya Ali Basar Tuanku Mudo dari

\footnotetext{
24 Wawancara dengan Ajo Labai Ketek Pada hari Jum'at 1 Sept 2017, Jam 14.30 di Tanjung Aur
}

Paninggahan Solok, dan Izzuddin Tuanku Malin Mudo dari Malalo.

Tahun 1974 menyematkan gelar tuankunya sebanyak lima orang, di antaranya Ahmad Dalwi Tuanku Labai Nan Mudo dari X koto, Darwis Tuanku Malin Marajo dari Kasang, Mhd Arif Tuanku Mangkuto dari Kayu Tanam, M. Rasyid Tuanku Dt. Rky Tuo dari X Koto, dan Tuanku Azhar Chan dari V Koto. Perayaan tahun ini dilaksanakan pada tahun 1974.

Pada tahun 1976 menyematkan gelar tuankunya sebanyak dua orang, yaitu Ahamsir Tuanku Malin Sinaro dari Kasang, dan Aly Imran Tuanku Khatib Marajo dari Malalo. Tahun 1978 menyematkan gelar tuankunya sebanyak lima orang, di antaranya Tuanku M. Nashiruddin dari X Koto, Tuanku Sukirman dari Rambatan, Ansyarullah Tuanku Khatib Bandaro dari X Koto, Daimal Irfan Tuanku Siddi Mangkuto dari VII Koto, Tuanku Basyaruddin dari Malalo.

Tahun 1979 menyematkan gelar tuankunya sebanyak empat orang, di antaranya Tuanku Abdur Rauf dari X Koto, Asman Syarif Tuanku Sutan Sinaro dari Kasang, Ahmad Zaini Tuanku Labai Batuah dari X Koto. Tahun 1980 menyematkan gelar tuankunya enam orang diantranya Bustanuddin Tuanku Bagindo dari VII Koto, Abdurrahim Tuanku Labai Batuah dari X Koto, Masrul Tuanku Khatib Batuah dari X Koto, Husin Alim Tuanku Sinaro dari X Koto, Syamsul Anwar Tuanku Khatib Rky Basa dari X Koto, M. Syafiyuddin Tuanku Marajo dari Kasang.

Tahun 1981 menyematkan gelar tuankunya sebanyak dua orang di antaranya M. Zaidi Tuanku Mudo dari Pariaman, dan Muazzuddin Tuanku Sutan dari Lubuk Alung. Tahun 1982 sebanyak sebanyak empat orang, di antaranya Buyung Adik Tuanku Faqiah Marajo dari X Koto, Idarussalam Tuanku Sutan dari RinganRingan, M. Yunus Tuanku Pakih Majolelo dari Malalo, Ali Akbar Khatib Bandaro dari Malalo. Tahun 1983 tidak ada yang tamat, dan tahun 
1984 menyematkan gelar tuankunya sebanyak empat orang di antaranya Zulfahmi Tuanku Paqih Majolelo dari Malalo, Syafruddin Tuanku Khatib Mulia dari $\mathrm{Tj}$ Gadang Sijunjung, Erman Tuanku Paqih Mudo dari Malalo, dan Marjohan Tuanku Mudo dari Cerenti Riau.

Tahun 1985 menyematkan gelar tuankunya sebanyak sebelas orang, di antaranya Zakirman Tuanku Paqih Sutan dari Malalo, Zubir Tuanku Malin Palito dari Tj Gadang Sijunjung, Suardi Tuanku Andah dari VII Koto, Tuanku. Khairul Basri Dt. Banuansa dari Tj Barulak, Zamadin Tuanku Malin Majolelo dari Singgalang, Tuanku Abu Bakar dari Lb Alung,Tuanku Zamzami dari Tarusan Pesisir Selatan.

Tahun 1986 menyematkan gelar tuankunya sebanyak empat orang di antaranya Ardison Tuanku Bagindo dari Aripan Solok, Ali Umar Tuanku Mudo dari Lb Alung, M. Ali Tuanku Paqih Majolelo dari Malalo, dan Isben Tuanku Majolelo dari Paninggahan Solok. Tahun 1987 menyematkan gelar tuankunya sebanyak dua orang yaitu, Tuanku M. Luthfi dan Almuhdil Karim Tuanku Bagindo dari Ringan-Ringan.

Tahun 1988 menyematkan gelar tuankunya sebanyak enam orang yaitu, Dhamiri Tuanku Malin Ameh dari Bungus, Akmal Tuanku Sidi dari Pariaman, Syarifuddin Tuanku Malin Bandaro dari Koto VII Sijunjung, M. Salim Tuanku Sutan dari Kayu Tanam, Darnis Tuanku Labai Sati dari Gunung Rajo, dan Iswanti Tuanku Paqih Kayo dari Malalo.

Tahun 1989 menyematkan gelar tuankunya sebanyak sepuluh orang yaitu, Akmaluddin Tuanku Labai Mudo dari Tj Barulak, Aziz Akbar Tuanku Basa dari Pariaman, Hasnal Tuanku Paqih Majolelo dari Malalo, Mailius Tuanku Sinaro dari Kuncir Solok, Dasrizal Tuanku Kh. Sulaiman dari Bungo Tanjung Batipuh, Mawardi Tuanku Sutan Salim dari Sungai Limau, Nasrul Tuanku Mudo dari Tj Gadang Sijunjung, Arminas Tuanku Malin Marajo dari Malalo, Safi'I Tuanku Sidi dari Asam Pulau, dan Masri Tuanku Mudo dari Lubuk Alung.
Tahun 1990 menyematkan gelar tuankunya sebanyak lima orang yaitu, Ahmad Damanhuri Tuanku Sutan Bandaro dari VII Koto, Hartono Tuanku Malin Mamgkuto dari Batipuh, Ali Basar Tuanku Sutan Sinaro dari VII Koto, Syamsul Akmal Tuanku Sutan dari VII Koto, Syafrimal Tuanku Paqih Marajo dari Malalo.

Tahun 1991 menyematkan gelar tuankunya enam orang yaitu, Tuanku Alius dari Malalo, Bujang Tuanku Sulaiman dari IV Koto, Zal Fitri Tuanku Makdum dari Aripan Solok, Irman L Tuanku Sutan Bandaro dari VII Koto, Jamaril Tuanku Mudo dari Bungus, Tuanku Syafrizal dari Sintoga.

Tahun 1992 menyematkan gelar tuankunya tiga belas orang yaitu Tuanku Amrizal dari VII Koto, Tuanku M. Yusuf Salam dari Bungus, Ustazah Yanti Ermita dari Kayu Tanam, Tuanku Syafrial dari $\mathrm{Tj}$ Aur, tuanku Abdul Malik dari VII Koto, Tuanku Jainal dari Rambatan Batu Sangkar, Tuanku Fikran Ahmadi dari Solok, Tuanku M. Nur Ali dari Sungai Tarab, Tuanku Muhammad Nur dari Sibarambang Solok, Tuanku Mhd Nazir dari Kayu Tanam, Tuanku Mismaruddin dari Malalo, Ustazah Arafatil Huda dari Kayu Tanam, dan Tuanku Ali Basar dari VII Koto.

Tahun 1993 menyematkan gelar tuankunya Sembilan orang yaitu, Zul Hamdi Tuanku Kerajaan Nan Saliah (tahun 2017 menjadi khalifah Syekh Ali Imran Hs dengan gelar Syekh Zul Hamdi Tuanku Kerajaan Nan Saliah) dari Sungai Tarab, Busyarli Tuanku Kuniang dari Sungai Limau, Tuanku ArmanYedi dari VII Koto, Tuanku Zulfahmi dari Malalo, Tuanku Nasir dari Malalo, Tuanku Zulkifli dari Ps Usang, Tuanku Rasman dari Batipuh, M. Rais Tuanku Labai Nan Basa dari Singgalang, $\mathrm{X}$ Koto, dan Tuanku Kusyairi dari RinganRingan.

Tahun 1994 menyematkan gelar tuankunya sebanyak empat orang yaitu, Tuanku Syaiful dari Ringan-Ringan, Tuanku Ihsan dari Sungai Tarab, Ustazah Zainab dari VII Koto, Tuanku Irfatmizon dari Batipuh. Tahun 1995 
sebanyak tiga orang yaitu, Tuanku Syafrizal dari Bungus, Tuanku Sumardi dari Kudu Gantiang, dan Tuanku Delfa Yenedi dari Batipuh.

Tahun 1996 menyematkan gelar tuankunya sebanyak empat belas orang yaitu, Tuanku Syahril dari Sintoga, Tuanku Zainal dari Lubuk Alung, Tuanku M. Nur dri Malalo, Tuanku Kisman dari Bungus, Tuanku Ali Musri dari Malalo, Tuanku Azrul Aswat dari VII Koto, Tuanku Herman dari Lubuk Minturun, Tuanku Jasril dari Bungus, Ustazah Siet dari Bungus, Tuanku Afrizal dari VII Koto, Tuanku Arius dari Malalo, Tuanku Mulyadi dari Pariaman, Tuanku Hendri Naldi dari Tandikek, dan Ustazah Hamidah dari VII Koto.

Tahun 1997 menyematkan gelar tuankunya sebanyak tiga belas orang yaitu, Tuanku Harmen Agustian dari Malalo,Tuanku Rahmat dari Lb Alung, Tuanku Masrizal dari Duo Koto, Tuanku M. Yusuf dari Bungus, Tuanku Syamsu Rijal dari Gunung Rajo, Tuanku Masripul dari Kasang, Tuanku Zul Fahmi dari Sungai Geringging, Tuanku Armayulis dari Agam, Tuanku Muslim dari Ringan-Ringan, Tuanku Syafriyulis dari Kayu Tanam, Zulkifli Tuanku Rajo Intan dari Pesisir Selatan, Tuanku Masripul dari Bungus, dan Tuanku Akmal dari Batipuh.

Tahun 1998 menyematkan gelar tuankunya dua puluh tujuh orang yaitu, Tuanku Assaidul Akram dari Aripan Solok, Ustazah Roni dari Duo Koto, Tuanku Jefrianto dari Bungus, Ustazah Misnita dai Malalo, Tuanku Goderman dari Bungus, Ustazah Nova Yendri dari Malalo, Tuanku Muslim dari VII Koto, Ustazah Armailis dari Ringan-Ringan, Tuanku Zumkasri, Tuanku Husni Tamrin dari Gunung Rajo, Tuanku Edi Edison dari Pd Panjang, Tuanku Junaidi dari Bangko Jambi, Tuanku Ali Abas dari Rimbo Panjang Riau, Tuanku Roni Wardi dari Malalo, Tuanku Syamsir, Tuanku Henadri, Tuanku Ujang Hartadi dari Pariaman, Tuanku Mursyidin Pincuran Tujuh, Tuanku Yatno dari Sawah Lunto, Tuanku Syarbaini dari Sintoga, Tuanku Inaldi dari Malalo,
Tuanku Syamsu Rijal, Ustazah Deswita dari Malalo, Tuanku Abdul Salam dari Pariaman, Tuanku Syafrisal dari Sijunjung, dan Tuanku Suharli dari Batu Sangkar.

Tamat tahun 1999 menyematkan gelar tuankunya Sembilan orang dan merayakan pengangkatan tuankunya tahun 2000 di antaranya, Ustazah Nurhasmi, Tuanku Ilham Mukhlis dari Pariaman, Ustazah Desmira Mulia dari Ringan-Ringan, Tuanku Abidur Rahman dari Kasang, Tuanku Leka Aini Zuhri, Ustazah Marlis dari Malalo, Tuanku Ismail dari Batipuh, Tuanku Zaherman dari Sungai Geringging, Tuanko Canon dari Kayu Tanam. Tamat tahun 2000 dan merayakan tahun 2000 adalah, Tuanku Deri Apendi dari Aripan Solok. ${ }^{25}$

Setelah pengangkatan tuanku tahun 2000 Syekh Ali Imran tidak lagi mengajar di kelas tujuh dikarenakan uzur dan sakit mata. Hingga tahun 2010 terjadi beberapa kali pergantian guru di kelasg VII di antaranya:

1. Zul Hamdi Tuanku Kerajaan Nan Sholeh. ${ }^{26}$ dari tahun 2001 sampai 3003. Setelah tahun 2003 beliau menggantikan Syekh Ali Imran mengajar di kelas Busthan dan mengajarkan tasawuf.

2. Busyrali Tuanku Kuniang dari tahun 2004 sampai 2005. Setelah tahun 2005 beliau dimintak masyarakat Sungai Geringging untuk mengajar disana.

3. Muhammad Rais, SS Tuanku Labai Nan Basa dari tahun 2006 sampai 2010.

Adapun mereka yang menyematkan gelar tuankunya dimasa Zul Hamdi Tuanku Kerajaan Nan Sholeh dimulai dari tahun 2001 adalah, sebanyak 17 orang, di antaranya Mhd Syafei Tuanku Labai Pandito dari Batipuh, Deri Efendi Tuanku Sutan Bagindo dari Solok, M Zali Sadana Tuanku Sinaro Mangkuto dari

\footnotetext{
25 Buku Daftar Ijazah M.A.I. Pondok PesantrenNurul Yaqin.

26 Wawancara dengan Syaiful Tk Mudo Hari Jum'at Tgl 18 Mei 2017 di Masjid Ringan-Ringan pukul 14.00 WIB
} 
Pasaman, Bukhari Tuanku Kuniang dari Sungai Kasikan, Ahmad Yani Tuanku Sidi dari Pauh Manis, Zul Hamdi Tuanku Mudo dari Malalo, Sutriani Ustazah Ma'adinul Hikami dari Solok, Yunila Sari Ustazah Hakimatum bil A'dlidari Lb Begalung, Nel Hasrati Ustazah Jami'atul Ma'rufi dari Tj Aur, Masriadi Tuanku Paqih Majolelo dari Malalo, Khadri Tuanku Paqih Sutan dari Malalo, Novis Tuanku Paqih Mandaro dari Malalo, Syahlul Munal Tuanku Majolelo Mangkuto dari Kudu Pariaman, Marison Tuanku Imam Saliah dari Inuman Riau, Mhd Darwis Tuanku Paqih Malin Kayo dari Batipuh, Sirajul Afkar Tuanku Qodhi dari Aripan Solok, HM Yasir Tuanku Labai Majolelo dari Batipuh.

Tahun 2002 menyematkan gelar tuankunya sebanyak 12 orang di antaranya Hunan Tuanku Sidi, Syaiful Rahman Tuanku Mudo Maharajo, Jamanir Tuanku Bagindo, Ori Sativa Syakban Tuanku Imam Rajo Basa, Sulthanul Yusra Tuanku Imam Mandaro, Syamsuddin Tuanku Mudo, Deflengki Tuanku Malin Mancayo, Tuanku Zainul Arif, Zulkarnaini Tuanku Paqih Majolelo, Ian Hasan Putra Tuanku Lb Sulaiman, Fadril Aziz Nain Tuanku Paqih Marajo, Zulfadli Tuanku Sutan.

Tahun 2003 menyematkan gelar tuankunya sebanyak lima orang, di antaranya M Asyraful Anam Tuanku Bgd Batuah dari Koto Tinggi Pdg Pariaman, Indra Gusnedi Tuanku Malin Sulaiman dari Bungus, Abrar Maulana Tuanku Khatib Majolelo dari Muaro Ambius, Mukhlis Tuanku Qori dari Ringan-ringan Pakandangan, Budiman Tuanku Labai Mudo dari Sungai Geringging.

Santri yang menyematkan gelar tuankunya tahun 2004 sampai tahun 2005 adalah di bawah bimbingan Busyrali Tuanku Kuniang ketika di kelas VII nya. Di antarasantri yang tamat tahun 2004 adalah sebanyak delapan orang di antaranya Ismaria Al Ustazatul Shadiqiyyah dari Sintoga, Azizah Mu'allimatun Mutimatunddin dari Tapakis Ulakan, Johari Jamal Tuanku Paqih Mudo dari Malalo,
Gustami Tuanku Simarajo Bungsu, Nursyamsi Gucci, Al Ustazatul Radiatul Bil Islam, Erman Tuanku Malin Basa, Darwinisah Tuanku Labai Mudo, Roza Arlantika Al Ustazatul Kamilah.

Tahun 2005 menyematkan gelar tuankunya sebanyak dua belas orang, tapi merayakan perayaan pengangkatan tuank $u$ dan ustazahnya bergabung dengan perayaan tahun 2006 yang berjumlah sebelas orang. Tahun 2006 guru kelas VII nya adalah M Rais SS, Tuanku Labai Nan Basa. Jadi jumlah santri yang merayakan pengangkatan tuanku tahun 2006 sebanyak 23 orang, yang terdiri dari 12 orang yang menyematkan gelar tuankunya dengan Busyrali Tuanku Kuniang dan 11 orang yang menyematkan gelar tuankunya dengan M Rais Tuanku Labai Nan Basa. Di antara mereka adalah M Yani Tuanku Mudo, M Idrus Tuanku Bandaro Sati, M Yalil Tuanku Basa, Junaidi Arif Tuanku Sidi Mangkuto, Jaliyul Azizi Ustazah Muhajiratul Haq, Mitratul Rahma, Ustazah Shadiqatum Bil Ilmi, Fitri Julina Ustazah Rahimatud-din, Muhardi Tuanku Malin Sutan, Fauzi Tuanku Malin Batuah, Murni Ustazah Hanifah, Ustazah Erdawati, dan Tuanku Ilyas. Selanjutnya Nofriandi Tuanku Mursyidul Ummah, Ahmadul Hadi Tuanku Mudo, Fajrul Khairi Tuanku Makhdun Sati, Hengki Afriko Tuanku Paqih Majolelo, M Al Munawir Tuanku Sidi Ibrahim, Rifqul Manan Tuanku Malin Sampono, Ustazah Reni Sri Wahyuni, Afrizal HD Tuanku Bandaro Kayo, Zelfa Yuli Tuanku Itam, Ika Syafrianto Tuanku Bagindo, Ilyas Tuanku Bagindo.

Yang menyematkan gelar tuankunya tahun 2007 sebanyak lima orang, di antaranya Mukimal Afkar Tuanku Sutan Sati dari Bintungan Tinggi, Repi Ramadhani Mu'allimah Mutaghiyatu Ridwanallah dari Pessel, Alfian Tuanku Malin Marajo dari Lb Alung, Mufti Ulil Amri Tuanku Labai Nan Basa dari Dumai Riau, Tuanku M Rasyid dari Malalo.

Tamat tahun 2008 sebanyak delapan belas santri di antaranya, Ilham Sikumbang Tuanku 
Bgd Kaciak dari Binuang, Rimandianto Tuanku Parmato Rajo Nan Alim dari Aripan Solok, Luki Permansyah Tuanku Bagindo dari Kayu Tanam, Ghina Rahmika Ust Mudawimatul I'badah dari Malalo, Dina Murni Ust Mudawimatud-din dari Malalo, Nel Hasrat Ust Mushlihatul Ummah dari Pdg Panjang, Nurhayati Ust Muslihatud-din dari Btg Masang, Tuanku Aguslim dari Kayu Tanam, Tuanku Abdul Muthalib dari Sungai Langkok, Tuanku Al Anshori dari Bengkulu, Irsyad Tuanku Malin Batuah dari Kasang, Ustazah Irmawati dari Malalo, Tuanku Zeki Ninofriko dari Sungai Sarik, Tuanku Ramadhani dari Pdg Pariaman, Muslim Tuanku Marajo Mangkuto Sati, Ahmad Syukur Tuanku Faqih Basa dari Singgalang, Tuanku Usman, dan Tuanku Erianto,

Tahun 2009 menyematkan gelar tuankunya dua belas santri yaitu, Roby Seprya Tuanku Karik Bayuan dari Pesisir Selatan, Afdal Yusra Tuanku Rajo Timbalan dari Bungus, Yosrizal Tuanku Sinaro Mudo dari Sintoga, Wezi Afrinal Tuanku Faqiah Mudo dari Malalo, Marjoni Tuanku Labai Bandaro Kayo dari Kayu Tanduak, Ahmad Syarif Tuanku Mudo Mankuto dari Asam Pulau, Zainal Abidin Tuanku Labai Batuah dari Gunung Rajo, Muhvi Evendi Tuanku Kaciak Rajo Endah dari Singgalang, Raflis Tuanku Faqiah Sutan dari Gunung Rajo, Maizatur Rasyidah Mu'alimatum Murayaqinah dari Gunung Rajo, Fauzan Ahmad Tuanku Malin Kayo Sinaro dari Kasang, Abuzar Alfarisi Tuanku Basa dari VII Koto, Risman Tuanku Faqiah Sinaro dari Singgalang, Mhd Nasri Tuanku Sutan dari VII Koto, Afradul Abrar Tuanku Bgd Sati dari Bungus, dan Tiflatul Hamida Mu'alimatun Jazimah dari Malalo.

Tahun 2010 menyematkan gelar tuankunya 20 orang santri di antaranya Elva Mahmudi Tuanku Khatib Majolelo dari Malalo, Ahmad Amin Tuanku Malin Marajo dari Ps Usang, Zahidatul Mardiyah Malimah Mu'atamidatum Bidinil Islam dari Aripan Solok, Anwar Hidayat Tuanku Qasidal Ilmi dari Pariaman,
Ade Dasrial Tuanku Sutan Mudo dari Sintuk, Hendri Tuanku Faqih Sinaro dari Pdg Sago, M Yunus Tuanku Malin Bandaro dari Asam Pulau, Rismanto Tuanku Khatib Panduko, Ibrahim Saleh Tuanku Rajo Mudo, Novis Afria Safitri Mu'alimah Mutaqidatum Bi'atiqadil Haq, Welzani Tuanku Rajo Bujang, Fatimatul Zahra Mu'alimah Kharijatum Minal Bathili Ilas Shaliah, Eko Ona Sutra Tuanku Sinaro, Shahluddin Tuanku Imam, M Fauzi Tuanku Bandaro Sati, Rici Ricardo Tuanku Sutan Majolelo, Ebri Salmi Tuanku Malin Mangkuto, Syamsul Mu'arif Tuanku Sidi, Anca Rais Tuanku Labai Marajo, dan Anasril Tuanku Malin Batuah.

Selanjutnya bagi santri yang sudah pernah mengajar dikelas VII atau yang dianggap ilmunya sudah sempurna diberi gelar oleh Abuya Syeikh Ali Imran dengan tambahan Syeikh Muda.

Secara garis besar pengelompokkan alumni yang dilahirkan di Pondok Pesantrn Nurul Yaqin dapat dipilah menjadi enam bagian:

1. Pertama, alumni yang mendirikan pondok Pesantren yang sejenis dengan pondok Pesantren Nurul Yaqin yang akhirnya menciptakan jaringan baru Nurul Yaqin,

2. Kedua sebaran alumni sesuai dengan daerah asalnya, dan

3. Ketiga alumni yang mempunyai ketrampilan khusus,

4. Keempat alumni yang berbeda tarekat dengan Syekh Ali Imran,

5. Kelima tradisi yang menjadi ikatan di Nurul Yaqin,

\section{Klasifikasi Alumni Sebagai Jaringan Pondok Pesantren Nurul Yaqin Dari 1970-2010}

Klasifikasi alumni dalam pembahasan ini diukur sesuai dengan pemanfaatan fungsinya, di mana sebagian alumni dianggap menjelaskan persoalan-persoalan yang diangkat oleh kalangan tradisional di Pesantren Nurul Yaqin dan sebaran pengaruhnya dalam 
hubungannya dengan respon mereka terhadap perubahan, dan oleh karena itu dianggap penting diangkat, dan sebagian lain adalah jaringan menciptakan fenomena baru dalam jaringan keguruan pondok Pesantren .

Data yang penulis temukan dilapangan sampai tahun 2010 murid-murid yang sudah menyematkan gelar tuankunya dan dianggap sudah berpengalaman sehingga diberi izin oleh Syekh Ali Imran untuk mendirikan lembaga pendidikan sejenis dengan Nurul Yaqin ditempat mereka maing-masing, dengan ketentuan mereka harus menggunakan nama Nurul Yaqin sebagai konsep utama dan mengajarkan kitab-kitab yang diajarkan di Nurul Yaqin ditempat mereka.

\subsection{Klasifikasi Alumni Nurul Yaqin}

Di antara murid-murid yang telah mendirikan Pesantren baru yang menjadi cabang Nurul Yaqin Ringan-ringan dan merupkan afiliasi dari Nurul Yaqin adalah sebagai berikut:

\section{a. Ahmad Damanhuri Tuanku Sutan Bandaro, beliau adalah putra kelahiran} Ampalu Sungai Sariak (Kecamatan VII Koto) tanggal 11 September 1969 dan menyematkan gelar tuankunya tahun 1990 dengan nomor ijazah 01/72/AL/1990. Dilihat dai nomor ijazah menandakan Ahmad Damanhuri adalah lulusan terbaik ditahun 1990 itu, hal ini diterangkan dengan angka satu di awal nomor ijazahnya. Kemudian beliau mengabdi selama lima tahun di Pondok Pesantren Nurul Yaqin selama lima tahun dan terakhir mengajar di kelasg V (kategori kelas tinggi).

Selama menjadi guru Ahmad Damanhuri juga mengikuti pelajaran di kelas Busthan, yaitu kelas tinggi yang diikuti oleh santri yang sudah menyematkan gelar tuankunya kelas VII (sudah menjadi Tuanku)di Pondok Pesantren Nurul Yaqin, lama belajar kelas di kelas busthan paling cepat dua tahun karena busthn terdiri dari dua tingkat yaitu Busthan 1 dan Busthan 2. Gelar bagi mereka yang sudah menyelesaikan di kelas busthan adalah Ahli Muhaqiqin bagi busthan 1 dan Ahli Mudaqiqin bagi busthan $2 .^{27}$

Setelah lima tahun mengabdi di Ringanringan Ahmad Damanhuri beserta beberapa alumni yang berasal dari VII Koto sepakat mendirikan Pesantren di negeri asal mereka, di antaranya Ali Basar Tuanku Sinaro, Tuanku Azrul Aswat. Dengan memohon izin kepada Syekh Ali Imran, dengan izin Syekh Ali Imran akhirnya dibeli tanah di Desa Ambuang Kapua Kenagarian Padang Sago seluas 1 Ha. Tahun 1996 mulailah Pondok Pesantren ini beroperasi dengan nama Pondok Pesantren Nurul Yaqin Ambuang Kapua. Sampai hari ini sudah menyematkan gelar tuankunya santri dan jumlah santri yang belajar sebanyak 400 santri. Tuanku Ahmad Damanhuri dibantu oleh Syahril Tuanku Sutan, Tuanku Amrizal.

b. Dhamiri Tuanku Malin Ameh. Putra bungus Teluk Kabung ini lahir 4 September 1958, dan menyematkan gelar tuankunya dengan peringkat terbaik tahun 1988, dengan nomor ijazah 01/56/AL/1988. Tuanku Malin Ameh lebih dikenal dengan panggilan Tuanku Dhamiri. Sebelum belajar ke Nurul Yaqin, Tuanku Dhamiri telah menyematkan gelar tuankunya di Surau Tuanku Tawaf Sungai Sariak tahun 1984, dan meneruskan belajar di Ringan-ringan dari tahun 1984. Dari tahun 1988 tuanku Dhamiri dipercaya mengajar di kelasg IV, tahun berikutnya di kelasg $\mathrm{V}$, dn terakhir mengajar di kelas VI sampai tahun 2001.

Ditahun yang sama abuya Ali Imran ke Manggopoh karena permintaan

27 Wawancara dengan Ahmad Damanhuri Tk Sutan Basa tanggal 6 Juni 2017 jam 14.00 WIB 
masyarakat disana untuk mengajar mereka dengan mendirikan pondok Pesantren , lebih kurang tiga bulan di Manggopoh, Syekh Ali Imran diberi lahan 38 hektar untuk bangunan pondok Pesantren dan 1000 hektar kebun sawit, dan memberi nama pondok Pesantren Nurul Yaqin Sitti Manggopoh. Setelah tiga bulan Syekh Ali Imran mengutus Dhamiri Tuanku Malin Ameh untuk menggantikannya di Manggopoh. Syekh Ali Imran kembali ke Ringan-ringan. Pembantu tuanku Damiri di antaranya Tuanku Kisman, tuanku Mursyidin. $^{28}$

c. H.M. Jali Sadana Tuanku Sinaro Mangkuto, putra Pasaman ini menyematkan gelar tuankunya di Pondok Pesantren Nurul Yaqin tahun 2001. Sebelum belajar ke Ringan-ringan beliau pernah belajar di Pondok Pesantren Darussalam Tsalis, dan meneruskan ke Pondok Pesantren Darul Mursyiddin. Setelah menyematkan gelar tuankunya Tuanku Jali hendak pulang ke Pasaman, tapi Syekh Ali Imran tidak mengizinkan dan menyuruhnya untuk tinggal di Lubuk Alung. Tahun 2009 Tuanku Jali membeli tanah di Kasiak Putiah Singguliang, di mana Syekh Ali Imran dulu pernah berkeinginan membangun Surau di Kasiak Putiah tersebut. Tahun 2010 tuanku Jali memohon izin kepada Syekh Ali Imran untuk membangun Pesantren dilahan yang telah dibelinya tersebut, maka abuya Ali Imran langsung memberi izin dan memberinya uang 500.000,- rupiah untuk pembeli bahan, maka sejak itu berniatlah tuangku jali bahwa " sungguahpun ambo nan mambangun Surau, tapi hakikatnyo buya nan mambangun". Mulai tahun berikutnya mulailah kegiatan belajar di

\footnotetext{
28 Wawancara dengan Tuanku Mursyidin tanggal 1 Agustus 2017 jam 16.00 WIB
}

kasiak Putiah, dan diberi nama Pondok Pesantren Nurul Yaqin Sadaniyyah. ${ }^{29}$

d. Zainal Tuanku Mudo dan Rahmat Tuanku Sulaiman, dua sudara ini menamat gelar tuankunya tahun 1996 dan 1997, dengan peringkat terbaik ditahun itu. Setelah tamat di Nurul Yaqin mereka mengabdi sebagai guru selama tiga tahun di kelas satu. Setelah itu menyambung ke perguraun tinggi hingga mencapai gelar Master sampai tahun 2005. Tahun 2006 mendapat izin dari Syekh Ali Imran untuk mendirikan pondok Pesantren dengan nama Bustan Nurul Yaqin. Sampai hari ini telah memiliki bangunan sebanyak 4 kelas dengan santri 100 orang. Guru bantu di Bustan Nurul Yaqin yang merupakan alumni Nurul Yaqin Ringan-ringan seperti Syahril Tuanku Sutan Basa, Syarbaini Tuanku Mudo Basa, Adrizal Tuanku Sutan, Muslim Tuanku Mangkuto, Syaipul Azhar Tuanku Malin. ${ }^{30}$

e. Husni Thamrin Tuanku Sinaro, putra Gunung Rajo kelahiran 5 Juli 1977 ini menyematkan gelar tuankunya Di Nurul Yaqin tahun 1998, kemudian mengabdi di Ringan-ringan mulai tahun 1998 sampai tahun 2004 dengan mengajar mulai dari kelas I sampai kelas VI. Tahun 2004 Tuanku Sinaro ini dimintak untuk mengajar di Gadur dan mendirikan Pondok Pesantren dengan nama Nurul Yaqin Surau Batu. Mulai dari tahun 2004 sampai tahun 2010 santri yang sudah menyematkan gelar tuankunya sebanyak 3 orang dan sekaligus menjadi pembantu beliau di Pesantren .

Di antara murid yang sudah menyematkan gelar tuankunya adalah Raflis Tuanku Malin dari Pdg Panjang, Syahruddin Tuanku Imam dari Sungai Geringging, Anca Rais

29 Wawancara dengan HM. Jali Sadana Tuanku Sinaro Mangkuto tanggal 1 Juli 2017 jam 16.30 WIB

${ }^{30}$ Wawancara dengan Zainal Tuanku Mudo tanggal 3 Januari 2018 jam 14.30 WIB 
Tuanku Labai Marajo dari Riau. Selain itu guru yang membantu di Surau Batu adalah Afrinal Tuanku Imam Sati yang merupakan adik kelas ketika belajar di Ringan-ringan. Jumlah santri Surau Batu berjumlah 60 orang dan sekarang yang sedang di kelas VII sebanyak empat orang. ${ }^{31}$

f. Bustami Tuanku Siddi Pamansiangan (1994), Ujang Artadi Tuanku Mudo Pamansiangan (1998)M. al-MunawirTuanku Siddi Ibrahim. Tiga bersaudara ini awalnya mengabdi di Nurul Yaqin, kemudian tahun 2006 atas izin Syekh Ali Imran mendirikan Pondok Pesantren di Padang Lunang Sungai Sariak tahun 2006. Sampai sekarang sudah memiliki santri 60 orang yang berasal dari sekitar Sumtera Barat dan suduh menyematkan gelar tuankunya santri sebanyak dua orang yaitu, Ramli Tuanku Malin Timbalan dari Bungus dan sekarang mengabdi di Pondik Pesantren Nurul Yaqin Alhikmah dan M.Syaifullah Tuanku Siddi Majolelo dari VII Koto dan menjadi guru di Pondok Pesantren Salahuddin Peti Kayu. ${ }^{32}$

\subsection{Sebaran Jaringan Guru Murid Pondok Pesantren Nurul Yaqin}

Sedangkan kategori kedua, adalah alumni dilihat sebaranya sesuai daerah asalnya sebagai bukti luasnya pengaruh Nurul Yaqin di selururh daerah di Sumatera khususnya Sumatera Barat dalam membentuk jaringan keilmuan,yang tidak hanya memberikan data yang berkaitan dengan respon masyarakat terhadap pondok Pesantren Nurul Yaqin dan sebaran pengaruhnya. Pada pembahasan ini akan dijelaskan data jaringan guru murid

${ }^{31}$ Wawancara dengan Tuanku Husni Tamrin tanggal 2 Februari 2018 jam $15.00 \mathrm{Wib}$

32 Wawancara dengan Siddi Munawir Tuanku Pamansiangan tanggal 3 Februari 2018 jam 16.00 WIB yang digunakan sebagai sumber utama disertasi ini, disertai dengan alasan pemilihannya berdasarkan viabilitasnya sebagai sumber sejarah.

Dari catatan lulusan Pondok Pesantren Nurul Yaqin dari tahun 1970 sampai 2010 dapat di kelasifikasi daerah yang banyak mengutus putra putrinya untuk belajar ke Nurul Yaqin, di antaranya sebagai berikut ${ }^{33}$ :

1. Malalo, mulai dari lulusan pertama sampai tahun 2010 daerah ini tidak pernah absen mengutus anak-anaknya menyematkan gelar tuankunya di Pondok Pesantren Nurul Yaqin Ringan-ringan, sehingga 40-50\% alumni Nurul Yaqin berasal dari Malalo. Hal ini tidak dapat dipungkiri karena Syekh Ali Imran lama belajar dan mengajar di Malalo dan selama di Malalo Syekh Ali Imran pernah mengajar kelas VII di MADRASAH TARBIYAH ISLAMIYAH Malalo selama 4 tahun, dan menjadi pembantu utama Syekh Zakaria Labai Sati selama di Malalo ${ }^{34}$, dengan sendirinya Syekh Ali Imran sangat disenangi masyarakat Malalo dan setelah Syekh Zakaria Wafat, masyarakat Malalo ingin anakanaknya diajar oleh orang kepercayaan Syeik Zakaria yaitu Syekh Ali Imran, bahkan anak dan penerus Syekh Zakaria belajar kepada Syekh Ali Imran di Ringan-ringan ${ }^{35}$ sebelum mengajar di MADRASAH TARBIYAH ISLAMIYAH Malalo. Secara wilayah asal sebaran jaringan Guru murid Syekh Ali Imran banyak berada di Malalo, hal ini sesuai dengan .

2. Lintau, dari awal berdirinya Nurul Yaqin santri dari Lintau sudah

\footnotetext{
33 Wawancara dengan Ali Musri Tuanku Malin tanggal 28 Desember 2017 jam 10.30 WIB

34 Wawancara dengan Syeikh Ali Imran tanggal 11 Januari 2017 jam 19.30 WIB

35 Buku Daftar Ijazah M.A.I. Pondok PesantrenNurul Yaqin
} 
meramaikan Ringan-ringan, hal ini disebabkan Syekh Ali Imran pernah diberi kepercayaan oleh Syekh Ibrahim Harun Tiaka di MADRASAH TARBIYAH ISLAMIYAH Tiaka mengelola Pakiah yang berasal dari Lintau. Ternyata hal ini menjadi ketertarikan bagi mereka, sehingga waktu Syekh Ali Imran mendirikan pondok Pesantren mereka juga pergi belajar ke Ringan-ringan ${ }^{36}$. Walaupun santri dari Lintau tidak bertahan sampai tahun 2010 tapi alumni Nurul Yaqin yang akhirnya menjadikan jaringan guru murid ke daerah lintau tetap ada. Sampai data terakhir yang penulis dapat bahwa sekitar 3 orang santri yang berasal dari Lintau telah menyematkan gelar tuankunya di Ringan-ringan.

3. Kayu Tanam, kawasan ini dari awal berdirinya Nurul Yaqin sudah mengutus putra terbaiknya untuk belajar di Ringan-ringan. Sampai data 2010 tercatat $10-15 \%$ alumni Nurul Yaqin adalah mereka yang berasal dari Kayu Tanam. Bahkan anak-anak mereka yang sudah tamat di Nurul Yaqin juga disekolahkan ke Nurul Yaqin atau mereka yang mrupakan jama'ah yang berasal dari Kayu Tanam juga menyekolahkan anaknya ke Nurul Yaqin seperti Faqiah Gigiah yang merupakan jama'ah Nurul Yaqin menyekolahkan anaknya seperti $\mathrm{H}$. Tasdikil Hamidi, Dariyah, bahkan mencari menantu juga berasal dari alumni Nurul Yaqin seperti suami Dariyah yaitu Alimusri Tuanku Malin dan anak Ali Musri Tuanku Malin yang bernama M.Syaiful Qolbi sekarang sedang mengaji di Pondok Pesantren Nurul Yaqin Ringan-ringan. Selain itu

\footnotetext{
36 Wawancara dengan Syeikh Ali Imran tanggal 2 Januari 2017 jam 16.30 WIB
}

Syekh Ali Imran dari awal juga dipercaya oleh Syekh Zakaria Labai Sati untuk menggantikan beliau wirid rutin di Kayu Tanam hingga Syekh Ali Imran wafat dan diteruskan oleh Syekh Zul Hamdi dan Syekh Muda Busyrali sampai sekarang. ${ }^{37}$ Jaringan guru murid Nurul Yaqin yang berasal dari Kayu Taman tercatat sekitar 10-15\%.

4. Tujuh Koto merupakan daerah dengan jumlah jama'ah Nurul Yaqin cukup banyak, bahkan cabang Nurul Yaqin juga juga ada disana seperti Nurul Yaqin Ambuang Kapua, Nurul Yaqin Aswaja. Penyebab putra daerah Sungai Sariak banyak menjadi santri Nurul Yaqin di antaranya Syekh Ali Imran pernah belajar kepada Salif Tuanku Kiramaik, wirid rutin ke Gobah Tuanku Salif Kiramaik, Syekh Hasan dan Syekh Ibrahim Hajji yang merupakan guru Syekh Ali Imran juga pernah belajar ke VII Koto. ${ }^{38}$ Dari data yang didapat alumni tertua yang berasal dari VII Koto adalah Bustami Tuanku Bagindo yang tamat tahun 1980. Kemudian juga diikuti oleh cucu Salif Tuanku Kiramaik seperti Tuanku Abdul Malik, Ustazah Hamidah, Latifah. ${ }^{39}$

5. Bungus, dari tahun 1988 tercatat setelah Dhamiri Tuanku Malin Ameh menyematkan gelar tuankunya di Nurul Yaqin dan sekaligus mengajar di Nurul Yaqin, maka mulailah putra putrid Bungus Padang mengaji ke Ringanringan, mereka menempati Surau Jariang sebagai asrama di Ringanringan. ${ }^{40}$ Dari catatan alumni jaringan

37 Wawancara dengan Ali Musri Tuanku Malin tanggal 28 Desember 2017 jam 10.30

38 Wawancara dengan M. al-Munawir Tuanku Siddi Ibrahim tanggal 5 Juni 2017 jam 19.30 WIB

39 Wawancara dengan Idarussalam Tuanku Sutan tanggal 3 Juli 2017 jam 19.30 WIB

${ }^{40}$ Wawancara dengan Elizal tanggal 30 November 2017 jam 11.00 WIB 
guru murid Nurul Yaqin yang berasal dri Bungus sekitar $10 \%$.

6. Solok, sejak tahun 1973 jaringan guru murid yang berasal dari Solok sudah mulai menyematkan gelar tuankunya di Nurul Yaqin, ditandai dengan tamatnya Ali Basir Tuanku Mudo putra ulama Solok yaitu Faqiah Abdul Munir menerima ijazah dengan nomor 011/AI/AL/Rr. Di antara putra putri Solok yang tamat ada beberapa yang berprestasi seperti Zal Fitri Tuanku Makhdum yang kemudian mendapat gelar Syekh Muda karena ketinggian ilmunya dan dipercaya mengajar kelas tinggi di Pondok Pesantren Nurul Yaqin. Dari catatan alumni Nurul Yaqin tercatat jaringan guru murid Nurul Yaqin sekitar 10\% berasal dari Solok. Informasi terakhir, di Solok sudah didirikan Cabang Nurul Yaqin dengan nama Nurul Yaqin ar-Rifki. ${ }^{41}$

7. Sepuluh Koto, daerah ini termasuk penyumbang jaringan guru murid terbanyak sesudah Malalo yaitu sekitar $20 \%$. Dimulai dengan tamatnya Ahmad Dalwi Tuanku Labai Nan Mudo tahun 1974 dan kemudian diangkat Syekh Ali Imran sebagai anak angkat beliau, sejak putra kelahiran 10-091949 di Air Hangat ini menyematkan gelar tuankunya, maka mulai banyak santri X Koto ini yang menyematkan gelar tuankunya. Di antara putra $\mathrm{X}$ Koto yang menjadi jaringan guru murid Nurul Yaqin ada beberapa orang yang menjadi pendiri cabang Nurul Yaqin di antaranya Husni Tamrin Tuanku Sinaro yang mendirikan Pondok Pesantren Nurul Yaqin Surau Batu, Akmaluddin Tuanku

41 Wawancara dengan M Asyraful Anam Tuanku Bagindo taggal 1 September 2017 jam 22.00 Wib
Bagindo yang mengabdi di Pondok Pesantren Darul Ulum Padang. ${ }^{42}$

8. Pariaman, sejak Tuanku Azhar Chan menyematkan gelar tuankunya tahun 1974 mulailah dihitung putra Pariaman menyematkan gelar tuankunya di Ringan-ringan. Setelah itu diikuti oleh M. Zaidi Tuanku Mudo tahun 1980. Sampai tahun 2010 tercatat sudah sekitar $5 \%$ alumni Nurul Yaqin yang berasal dari kota Pariaman. Sebagai jaringan keilmuan untuk wilayah ini tercatat ada beberapa orang yang merupakan lulusan yang diangkat menjadi Syekh Muda oleh Syekh Ali Imran, di antaranya Syekh Muda Busyrali Tuanku Kuniang dan sekarang mengabdi di Simpang limun Sungai Limau.

9. Sawah Lunto Sijunjung, sebagai pusat Syattariyah abad ke XVIII kawasan ini merupakan salah satu simpul ilmu Islam di zamannya. Syekh Hasan Tuanku Bagindopun pernah belajar kesana ketempat Syekh Malin Bandaro Koto VII, dan salah seorang murid Syekh Burhanuddin juga berasal dari sini yaitu Syekh Kadi Padang Ganting (Dt Maruhun Panjang). Alumni Nurul Yaqin yang berasal dari sini dimulai dri Syuryadi Tuanku Mudo anak dari seorang ulama yaitu Qunut Tuanku Labai Sutan Koto Baru. Jaringan guru murid Nurul Yaqin yang berasal dari sini sekitar $6 \%$ dan mereka rata-rata mengabdi di kampung halaman mereka sebagai ulama.

10. Pesisir Selatan, dihitung dari Tuanku Zamzami yang menyematkan gelar tuankunya tahun 1985 mulailah dihitung jaringan guru murid untuk kawasan Pesisir Selatan. Berturut-turut kemudian diikuti oleh Zulkifli Tuanku

42 Wawancara dengan Ali Musri Tuanku Malin tanggal 28 Desember 2017 jam 10.30 WIB 
Rajo Intan maka dapat dikatakan jumlah alumni dari sini hanya dua orang yang menyematkan gelar tuankunya.

11. Kasang. Daerah ini dari awal berdirinya Nurul Yaqin sudah mempunyai alumni yang merupakan jaringan guru murid. Dimulai dari Syamsir Alam Tuanku Malin Bagindo yang tamat tahun 1970, hingga Tuanku Fauzan Ahmad sudah tercatat $5 \%$ yang menjadi alumni. Sampai sekarang sudah ada yang diangkat jadi Syekh Muda yaitu Syafiuddin Tuanku Ancak dan telah mendirikan cabang Nurul Yaqin dengan nama Nurul Yaqin Surau Baru Kasang. Daerah ini juga menjadi pusat jama'ah Syattariyah Nurul Yaqin untuk kawasan Kecamatan Batang Anai.

12. Batu Sangkar. Dari Batu Sangkar alumni Nurul Yaqin sudah tercatat dari tahun 1978 yaitu putra Rambatan yang bernama Tuanku Sukirman. Secara keseluruhan santri yang sudah menyematkan gelar tuankunya yang merupakan jaringan guru murid Nurul Yaqin sekitar $5 \%$. Di antara murid Syekh Ali Imran yang terbaik, buya menjatuhkan pilihan yang paling baik kepada Zul Hamdi Tuanku Kerajaan Nan Sholeh Putra Sungai Tarab Batu Sangkar. Sejak Syekh Ali Imran Uzur seluruh kegiatan keilmuan diserahkan kepada Zul Hamdi. Terakhir Zulhamdi diberi gelar Syekh Zulhamdi Tuanku Kerajaan Nan Sholeh dan menjadi pengganti atau Kalifah Imrani setelah Syekh Ali Imran wafat. ${ }^{43}$

13. Ringan-ringan dan sekitarnya. Kawasan ini sebenarnya santri Nurul Yaqin sudah ada sejak berdirinya Nurul Yaqin seperti Idris Tuanku

43 Wawancara dengan Muhammad Asyraful Anam Tk Bagindo tanggal 3 Agustus 2017 jam 21.30 WIB
Kuniang, Muslim Rasyid Tuanku Pamuncake Majolelo, Tuanku Sirajul Afkar, tapi kartena pencatatan dalam tesis ini dimulai dari 1970 maka dikawasan ini mulai menciptakan jaringan guru murid dimulai dari Muazzuddin Tuanku Sutan yang tamat tahun 1981, Idarussalam Tuanku Sutan tahun 1982, Almuhdil Karim Tuanku Bagindo tahun 1984, Tuanku Abu Bakar tahun 1985, dan lain-lain. Dari keseluruhan Jaringan guru murid untuk kawasan ini sekitar $5 \%$.

14. Luar Sumatera Barat. Untuk diluar Sumatera Barat sebenarnya muridmurid Nurul Yaqin sudah menyebar sampai ke Aceh Darussalam, tapi yang menyematkan gelar tuankunya hanya beberapa orang saja seperti Marjohan Tuanku Mudo dari Cerenti Riau tamat tahun 1984, Tuanku Junaidi dari Banko Jambi tamat tahun1998, Ali Abas dari Rimbo Panjang Riau tamat tahun 1998.

\section{Daftar Pustaka}

Amiruddin, Berjuang Tanpa Pamrih, (Pdg Pariaman: PEMDA Pdg Pariaman,2005)

Apria Putra Ulama-ulama Luak Nan Bungsu. Padang: Minangkabau Press,2011.h.200

Azyumardi Azra, Jaringan Ulama Timur Tegah dan Kepulauan Nusantara Abad XVII \& XVIII, Akar Pembaruan Islam di Indonesia, edisi revisi, Kencana, Jakarta:2007

Catatan Harian Syeikh Muda Muhammad Rais Tuanku Labai nan Basa.

Oman Fathurrahman, Tarekat Syattariyah di Minangkabau, (Jakarta:Prenada Media Group, 2008)

Sofyan Hadi, Tarekat Naqsabandiyah Khidiyah di Minangkabau (Jurnal Manassa Manuskripta Vol 1 No 2, 2011)

Buku Daftar Ijazah M.A.I. Pondok PesantrenNurul Yaqin.

Wawancara dengan Syeikh Ali Imran tanggal 2 Januari 2017 jam 16.30 WIB 
Wawancara dengan Tuanku Mursyidin tanggal 1 Agustus 2017 jam 16.00 WIB

Wawancara dengan M. al-Munawir Tuanku Siddi Ibrahim tanggal 5 Juni 2017 jam 19.30 WIB

Wawancara dengan Elizal tanggal 30 November 2017 jam 11.00 WIB

Abdul Muis (73) (dalam Armaidi Tanjung), Wawancara, Minggu, 18 September 2017 di kediamannya, Padang Laweh, Malalo. Imam Masjid Nurul Huda Padang Laweh Kecamatan Batipuh Selatan, khifah tarekat Naqsabandi sejak 1950.

Bainar (76) (dalam Armaidi Tanjng), wawancara, Minggu, 18 September 2017 di kediamannya, Padang Laweh, Malalo.

Wawancara dengan Ajo Labai Ketek Pada hari Jum'at 1 Sept 2017, Jam 14.30 di Tanjung Aur

Ajis Pakiah Mangkuto (80) (dalam Armaidi Tanjung), Wawancara, Minggu, 18 September 2016 di kediamannya, Padang Laweh, Malalo.

Wawancara dengan Ahmad Damanhuri Tk Sutan Basa tanggal 6 Juni 2017 jam 14.00 WIB

Wawancara dengan Ali Musri Tuanku Malin tanggal 28 Desember 2017 jam 10.30 WIB

Wawancara dengan Awaluddin Tk Mudo tanggal 16 Maret 2017. Jam 14.00 di Surau Mato Aia Sarang Gagak.

Wawancara dengan HM. Jali Sadana Tuanku Sinaro Mangkuto tanggal 1 Juli 2017 jam 16.30 WIB

Wawancara dengan Idarussalam Tuanku Sutan tanggal 3 Juli 2017 jam 19.30 WIB

Wawancara dengan M Asyraful Anam Tuanku Bagindo taggal 1 September 2017 jam 22.00 Wib

Wawancara dengan Muhammad Asyraful Anam Tk Bagindo tanggal 3 Agustus 2017 jam 21.30 WIB

Wawancara dengan Siddi Munawir Tuanku Pamansiangan tanggal 3 Februari 2018 jam 16.00 WIB

Wawancara dengan Syaiful Tk Mudo Hari Jum'at Tgl 18 Mei 2017 di Masjid RinganRingan pukul 14.00 WIB

Wawancara dengan Syeikh Ali Imran tanggal 11 Januari 2017 jam 19.30 WIB
Wawancara dengan Tuanku Husni Tamrin tanggal 2 Februari 2018 jam $15.00 \mathrm{Wib}$

Wawancara dengan Zainal Tuanku Mudo tanggal 3 Januari 2018 jam 14.30 WIB

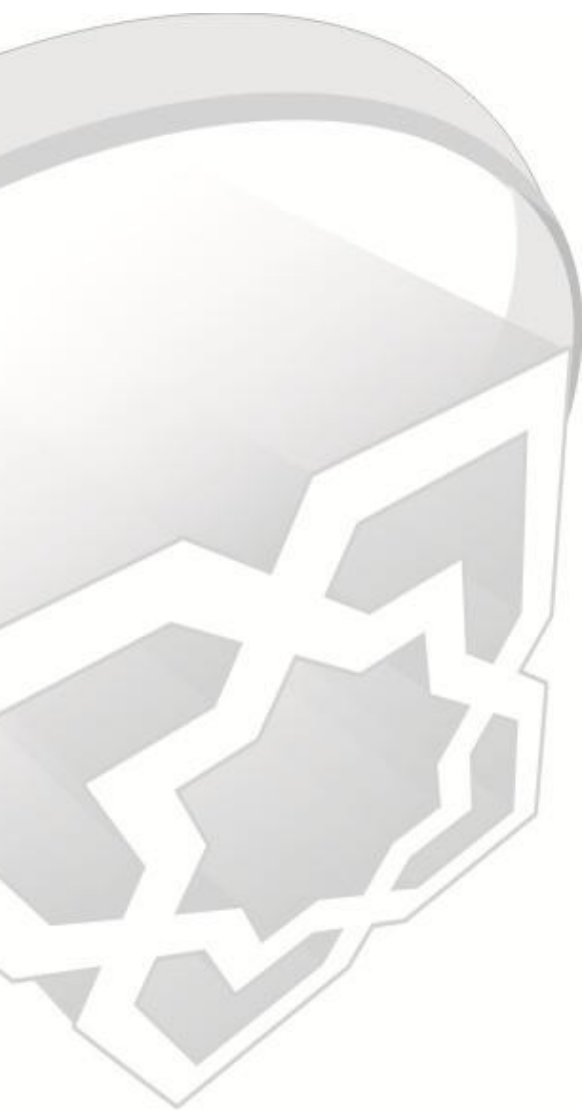

